\title{
A comparative study of serum calcium and magnesium levels in women with pre-eclampsia and normotensive women
}

\author{
Saloni Sethi, Ankita Chaudhary, Priya Sonkhya, Premlata Mital*, Aditi Arora, \\ Vikash K. Kasana, Ishita Agarwal
}

Department of Obstetrics and Gynaecology, S.M.S. Medical College, Jaipur, Rajasthan, India

Received: 09 April 2021

Accepted: 05 May 2021

\section{*Correspondence:}

Dr. Premlata Mital,

E-mail: drpremlatamital@gmail.com

Copyright: (c) the author(s), publisher and licensee Medip Academy. This is an open-access article distributed under the terms of the Creative Commons Attribution Non-Commercial License, which permits unrestricted non-commercial use, distribution, and reproduction in any medium, provided the original work is properly cited.

\begin{abstract}
Background: Pre-eclampsia is transient but potentially dangerous complication of pregnancy. Despite of preeclampsia's prevalence and severity, the pathophysiology of this multisystem disorder is still poorly understood and its aetiology has not yet been fully elucidated. Recently, nutritional deficiency especially micronutrients deficiency is gaining prominence in the pathogenesis of pre-eclampsia. Hypocalcaemia and hypomagnesaemia have been implicated in the pathogenesis of pre-eclampsia. This study has been done to compare serum calcium and magnesium levels in women with pre-eclampsia and normotensive women and their association with severity of pre-eclampsia.

Methods: 50 women with pre-eclampsia and 50 normotensive women were included in the study and serum calcium and magnesium levels were measured. Data were analyzed.

Results: The serum ionic calcium concentration was significantly lower in the pre-eclamptic cases compared to the normotensive controls $(3.34 \pm 1.35$ versus $4.37 \pm 0.74, \mathrm{p}=0.0000)$ similarly serum magnesium concentration was significantly lower in the pre-eclamptic cases compared to the normotensive controls $(1.68 \pm 0.41$ versus $1.94 \pm 0.42, \mathrm{p}$ 0.002). Mean serum ionic Ca levels in severe pre-eclampsia group was significantly lower than normotensive pregnant women $(\mathrm{p}=0.0000)$ as well as mild pre-eclampsia group $(\mathrm{p}=0.001)$. Mean serum $\mathrm{Mg}$ in severe pre-eclampsia was significantly lower than normotensive pregnant women $(\mathrm{p}=0.0008)$ as well as mild pre-eclampsia group $(\mathrm{p}=0.03)$. Serum ionic $\mathrm{Ca}$ and $\mathrm{Mg}$ had a negative correlation with systolic and diastolic blood pressure.

Conclusions: Based on this study, measurements of serum ionic calcium and magnesium among women at risk of for pre-eclampsia may be used to predict the onset and severity of pre-eclampsia.
\end{abstract}

Keywords: Pre-eclampsia, Serum ionic calcium, Serum magnesium

\section{INTRODUCTION}

Hypertensive disorders remain among the most significant and intriguing unsolved problems in obstetrics. These disorders complicate 5 to 10 percent of all pregnancies, and together they are one of the deadly triad-along with hemorrhage and infection that contributes greatly to maternal morbidity and mortality rates. ${ }^{1}$ Pre-eclampsia $(\mathrm{PE})$ is an idiopathic multisystem disorder specific to human pregnancy. ${ }^{1}$ It is defined as the onset of hypertension and the presence of proteinuria during pregnancy, usually occurring after the 20th week of gestation in a previously normotensive woman and resolving completely by the sixth week after delivery of fetus. ${ }^{2}$ Incidence of preeclampsia has been estimated at 5$14 \%$ pregnancies worldwide, $4-18 \%$ in developing countries with increasing trend and accounts for about 20$80 \%$ of the maternal mortality in developing countries. ${ }^{3,4}$

Despite of PE's prevalence and severity, the pathophysiology of this multisystem disorder is still poorly understood. The pathophysiological mechanism involved is characterized with the failure of the trophoblastic 
invasion of the spiral arteries, leading to mal-adaptation of maternal spiral arterioles, which may be associated with an increased vascular resistance of the uterine artery and a decreased perfusion of the placenta. ${ }^{5}$ The implicated vascular resistance and under-perfusion of the placenta may lead to the release of antiangiogenic factors into the maternal circulation and alter maternal systemic endothelial function to cause hypertension and other manifestations of the disease. ${ }^{6}$ Other contributory factors include obesity, diabetes, calcium deficiency, maternal age, and job stress. ${ }^{7}$

Recently, nutritional deficiency is gaining prominence in the pathogenesis of preeclampsia. It is assumed that deficiency of several essential micronutrients may be a predisposing factor in the development of PE because nutrients can modulate oxidative stress by increasing or decreasing free radicals or antioxidant and providing substrates for formation of free radicals. ${ }^{8}$ Nutritional deficiencies are commonly found in pregnant women and it is well established that the pregnant women from developing countries usually consume diets that are low in minerals and vitamins. ${ }^{9}$ Recently calcium and magnesium levels have been implicated in the pathogenesis of PE. On the physiological basis, calcium plays an important role in muscle contraction and regulation of water balance in cells. Modification of plasma calcium concentration leads to alteration of blood pressure. Calcium caused vasoconstriction by decreasing prostacyclin production and by increasing the vasoconstriction effect of angiotensin II and noradrenaline in the blood vessel wall. ${ }^{10}$ The lowering of serum calcium and the increase of intracellular calcium can cause an elevation of blood pressure in preeclamptic mothers so the modification of calcium metabolism during pregnancy could be one of the causes of pre-eclampsia. ${ }^{11}$ Several studies showed that significantly low serum calcium level in pre-eclamptic women as compare to normal pregnant $(\mathrm{p}<0.05) .{ }^{6,9,12}$ But in other studies serum levels of calcium did not differ significantly between pre-eclamptics and comparative group..$^{13,14}$

Generally, hypomagnesaemia in most of pregnant women is associated with haemodilution, renal clearance, consumption of minerals by the growing fetus. There is decrease in ionized and total magnesium levels with increasing gestational age during normal pregnancy, as well as evidence of magnesium disturbance in women who later developed PE. Magnesium levels may have significant effects on cardiac excitability and on vascular tone, contractility and reactivity. Magnesium causes vascular muscle relaxation. ${ }^{15}$ Pregnancy induced hypertension is characterized by vasospasm, elevated blood pressure and increased neuromuscular irritability, features common to syndromes of magnesium deficiency. ${ }^{10}$ Observational studies from medical records reported that magnesium supplementation during pregnancy was associated with reduced risk of preeclampsia. $^{16}$
There is limited local studies to know the serum levels of magnesium and calcium in Indian pregnant women (normotensive or pre-eclamptic) in Rajasthan so this study was designed to measure and compare serum levels of magnesium and calcium in normotensive and preeclamptic women. This study may give some clue whether routine monitoring of serum magnesium and calcium may have potential in the early detection of pregnant women at risk of PE and prophylactic calcium and magnesium supplementation during pregnancy could be recommended.

\section{METHODS}

This was a hospital based comparative, cross-sectional study conducted in the department of Obstetrics and Gynaecology, S.M.S. Medical College, Jaipur. Preeclamptic or normotensive women with live singleton pregnancy between 24 to 36 weeks of age, were willing to participate in the study were included. Women with medical disorders like diabetes, thyroid disease, renal or hepatic disorders, chronic hypertension, with signs of infection or in labour and with congenital malformation of foetus were excluded from the study.

\section{Sample size}

Sample size was calculated at $80 \%$ study power and alpha error 0.05 assuming standard deviation of $0.34 \mathrm{mg} / \mathrm{dl}$ in serum calcium level as per result of seed article. 7 For minimum detectable difference mean serum calcium level of $0.2 \mathrm{mg} / \mathrm{dl}$ between the groups. 45 cases in each group were required as sample size which was further enhanced and rounded off to 50 cases in each group as final sample size for present study expecting $10 \%$ attrition/ loss to follow up of patients.

The women included in the study after obtaining written informed consent detailed history and physical examination including blood pressure and urine for protein and other baseline investigations were done. Study group comprised 50 women with $\mathrm{PE}$ and control group comprised women with normal blood pressure (BP).

PE was diagnosed when systolic BP was $>140 \mathrm{~mm} \mathrm{Hg}$ and diastolic BP was $>90 \mathrm{~mm} \mathrm{Hg}$ with presence of proteinuria $>+1$ on dipstick. Women with PE were further categorized in to mild and severe.

Mild preeclampsia was characterized by systolic BP $>140$ and $<160 \mathrm{~mm}$ of $\mathrm{Hg}$ and diastolic BP $>90$ and $<110 \mathrm{~mm}$ of $\mathrm{Hg}$ and proteinuria $>+1$ and $<2$ dipstick.

Sever preeclampsia was characterized by systolic BP $\geq 160$ $\mathrm{mm}$ of $\mathrm{Hg}$ and diastolic $\mathrm{BP} \geq 110 \mathrm{~mm}$ of $\mathrm{Hg}$ and proteinuria $>+1$ and $<2$ dipstick with associated with symptoms like cerebral or visual disturbances, pulmonary edema, epigastric or right upper quadrant pain, intrauterine growth restriction, impaired liver function or thrombocytopenia. 
Serum ionic calcium and magnesium levels were measured.

All data collected were entered into Microsoft excel sheet and statistically analyzed. $\mathrm{P}$ value less than 0.05 was considered significant.

\section{RESULTS}

Table 1 shows mean systolic blood pressure (SBP) in preeclamptic women was $154.6 \pm 13.43 \mathrm{~mm}$ of $\mathrm{Hg}$ with a range of 140 to $200 \mathrm{~mm}$ of $\mathrm{Hg}$. Mean SBP in normotensive pregnant women was $112.8 \pm 8.34 \mathrm{~mm}$ of $\mathrm{Hg}$ with a range of 100 to $130 \mathrm{~mm}$ of $\mathrm{Hg}$. Difference in SBP between the two groups was statistically significant $(\mathrm{p}=0.0000)$.

Mean diastolic blood pressure (DBP) in pre-eclamptic women was $99.0 \pm 8.63 \mathrm{~mm}$ of $\mathrm{Hg}$ with a range of 90 to 120 $\mathrm{mm}$ of $\mathrm{Hg}$. Mean DBP in normotensive pregnant women was $73.0 \pm 5.05 \mathrm{~mm}$ of $\mathrm{Hg}$ with a range of 60 to $80 \mathrm{~mm}$ of $\mathrm{Hg}$. Difference in DBP between the two groups was statistically significant $(\mathrm{p}=0.0000)$.

Table 1: Comparison of systolic and diastolic blood pressure between the pre-eclamptic women and the normal pregnant women.

\begin{tabular}{|llll|}
$\begin{array}{l}\text { Mean } \\
\text { blood } \\
\text { pressure }\end{array}$ & $\begin{array}{l}\text { Study } \\
\text { group } \\
(\mathbf{n}=\mathbf{5 0})\end{array}$ & $\begin{array}{l}\text { Control } \\
\text { group } \\
(\mathbf{n}=\mathbf{5 0})\end{array}$ & P value \\
\hline $\begin{array}{l}\text { Mean } \\
\text { systolic BP } \\
\text { (SBP) }\end{array}$ & $154.6 \pm 13.43$ & $112.8 \pm 8.34$ & $\begin{array}{l}0.0000 \\
\text { significant }\end{array}$ \\
$\begin{array}{l}\text { Mean } \\
\text { diastolic } \\
\text { BP (DBP) }\end{array}$ & $99.0 \pm 8.63$ & $73.0 \pm 5.05$ & $\begin{array}{l}0.0000 \\
\text { significant }\end{array}$ \\
\hline
\end{tabular}

Table 2 shows socio-demographic profile of the women. Majority of the women in both groups were in 25-30 groups. Mean age of the women in study group and control group was $27.12 \pm 3.94$ and $24.9 \pm 2.98$ years. There was significant difference in the age in both groups $(\mathrm{p}=0.03)$. Majority of the women in study group were Hindu, literate, belonged to urban area and lower socio-economic status. Mean body mass index (BMI) in study group was significantly more than control group $(26.00 \pm 2.18$ versus $\left.24.34 \pm 2.12 \mathrm{~kg} / \mathrm{m}^{2} ; \mathrm{p}=0.0002\right)$.

Table 3 compares the levels of serum ionic calcium and magnesium in study group and control group. The serum ionic calcium concentration was significantly lower in the pre-eclamptic cases compared to the normotensive controls $(3.34 \pm 1.35$ versus $4.37 \pm 0.74, \mathrm{p}=0.0000)$ similarly serum magnesium concentration was significantly lower in the pre-eclamptic cases compared to the normotensive controls $(1.68 \pm 0.41$ versus $1.94 \pm 0.42, \mathrm{p}=0.002)$. These findings confirmed the hypothesis that hypocalcaemia and hypomagnesaemia may be etiological factors in development of preeclampsia.
Table 2: Socio-demographic profile of the women.

\begin{tabular}{|llll|}
\hline Variables & $\begin{array}{l}\text { Study } \\
\text { group } \\
(\mathbf{n = 5 0 )}\end{array}$ & $\begin{array}{l}\text { Control } \\
\text { group } \\
\text { (n=50) }\end{array}$ & $\begin{array}{l}\text { P } \\
\text { value }\end{array}$ \\
\hline $\begin{array}{l}\text { Mean age } \\
\text { (years) }\end{array}$ & $27.12 \pm 3.94$ & $24.9 \pm 2.98$ & 0.03 \\
\hline Residence & & 18 & 0.4 \\
\hline Rural & 22 & 32 & \\
\hline Urban & 28 & 24 & 0.8 \\
\hline Literacy status & & 26 & \\
\hline Illiterate & 25 & & \\
\hline Literate & 25 & 34 & 0.5 \\
\hline Religion & & 16 & \\
\hline Hindu & 37 & & 0.3 \\
\hline Muslim & 13 & 26 & \\
\hline SE status & & 23 & 0.6 \\
\hline Lower & 22 & 1 & 0.9 \\
\hline Middle & 24 & $2.1 \pm 1.04$ & \\
\hline Upper & 4 & $1.59 \pm 0.82$ & 002 \\
\hline Mean gravidity & $2.0 \pm 1.1$ & $24.34 \pm 2.12$ & 0.0002 \\
\hline Mean parity & $1.58 \pm 0.70$ & & \\
\hline $\begin{array}{l}\text { Mean BMI } \\
\text { (kg/m }{ }^{2} \text { ) }\end{array}$ & $26.00 \pm 2.18$ & 25 & \\
\hline
\end{tabular}

Association of mean serum (S.) ionic calcium (Ca) and magnesium $(\mathrm{Mg})$ with severity of PE is shown in Table 4. Mean S. ionic $\mathrm{Ca}$ in normotensive pregnant women was $4.37 \pm 0.74 \mathrm{mg} / \mathrm{dl}$, in mild PE group was $3.80 \pm 1.24$ and in severe PE was $2.74 \pm 1.28$.

Mean S. Ca levels in mild PE was lower than normotensive pregnant women but the difference was not significant $(p=0.05)$. Mean $\mathrm{S}$. Ca levels in severe PE group was significantly lower than normotensive pregnant women $(\mathrm{p}=0.0000)$ as well as mild PE group $(\mathrm{p}=0.001)$.

Mean S. Mg in normotensive pregnant women was $1.94 \pm 0.42 \mathrm{mg} / \mathrm{dl}$, in mild PE group was $1.79 \pm 0.30$ and in severe PE was $1.54 \pm 0.50$. Mean $\mathrm{S}$. $\mathrm{Mg}$ in mild PE was lower than normotensive pregnant women but the difference was not significant $(\mathrm{p}=0.2)$.

Mean S. Mg in severe PE was significantly lower than normotensive pregnant women $(\mathrm{p}=0.0008)$ as well as mild PE group $(\mathrm{p}=0.03)$.

Table 5 and Figure 1 and 2 show Pearson correlation of systolic and diastolic blood pressure with $\mathrm{S}$. ionic $\mathrm{Ca}$ levels. Serum ionic $\mathrm{Ca}$ had a significant moderate negative correlation with systolic $\mathrm{BP}(\mathrm{R}=-0.538, \mathrm{p}<0.0001)$ and diastolic BP $(\mathrm{R}=-0.5137, \mathrm{p}<0.0001)$.

Table 6 and Figure 3 and 4 show Pearson correlation of systolic and diastolic blood pressure with $\mathrm{S}$. Mg levels. Serum $\mathrm{Mg}$ had a significant weak negative correlation with SBP $(R=-0.3005, p=0.002)$ and with DBP $(R=-0.3252$, $\mathrm{p}<0.001)$. 
Table 3: Comparison of mean serum ionic calcium and serum magnesium levels in PE and normotensive women.

\begin{tabular}{|lllllll|}
\hline Parameters & Group & N & Mean & $\begin{array}{l}\text { Standard } \\
\text { deviation }\end{array}$ & $\begin{array}{l}\text { Standard error of } \\
\text { mean }\end{array}$ & P value \\
\hline \multirow{2}{*}{ S. calcium } & Study & 50 & 3.34 & 1.35 & 0.191 & 0.0000 \\
& Control & 50 & 4.37 & 0.74 & 0.104 & Significant \\
\cline { 2 - 7 } S. magnesium & Study & 50 & 1.68 & 0.41 & 0.58 & 0.002 \\
\cline { 2 - 6 } & Control & 50 & 1.94 & 0.42 & 0.59 & Significant \\
\hline
\end{tabular}

Table 4: Association of severity of PE with S. ionic Ca and Mg levels.

\begin{tabular}{|lll|ll|} 
Parameters & $\begin{array}{l}\text { Normotensive women } \\
(\mathbf{n = 5 0})\end{array}$ & $\begin{array}{l}\text { Women with mild PE } \\
(\mathbf{n = 2 8})\end{array}$ & $\begin{array}{l}\text { Women with severe } \\
\mathbf{P E}(\mathbf{n = 2 2})\end{array}$ & P value \\
\hline Mean S. Ca & $4.37 \pm 0.74$ & $3.80 \pm 1.24$ & $2.74 \pm 1.28$ & 0.004 \\
\hline Mean S. $\mathbf{M g}$ & $1.94 \pm 0.42$ & $1.79 \pm 0.30$ & $1.54 \pm 0.50$ & 0.001 \\
\hline
\end{tabular}

Table 5: Correlation of systolic and diastolic BP with serum ionic calcium levels.

\begin{tabular}{|l|lll|ll|}
\hline $\mathbf{N}=100$ & Mean \pm SD & R & R square & Equation & \multicolumn{2}{c|}{ P value } \\
\hline Systolic BP & $133.7 \pm 23.77$ & -0.538 & 0.2894 & $Y=-0.30 \times X+7.51$ & $<0.0001$ \\
\hline S. ionic calcium & $3.85 \pm 1.21$ & & $Y=-0.04 \times X+7.45$ & $<0.0001$ \\
\hline Diastolic BP & $86.0 \pm 14.84$ & -0.5137 & 0.2639 & $Y=1$ & \\
\hline S. ionic calcium & $3.85 \pm 1.21$ & & &
\end{tabular}

Table 6: Correlation of systolic and diastolic BP with serum magnesium levels.

\begin{tabular}{|c|c|c|c|c|c|}
\hline $\mathrm{N}=100$ & Mean \pm SD & $\mathbf{R}$ & R square & Equation & P value \\
\hline Systolic BP & $133.7 \pm 23.77$ & \multirow{2}{*}{-0.3005} & \multirow{2}{*}{0.0903} & \multirow{2}{*}{$Y=-0.01 \times X+2.55$} & \multirow{2}{*}{0.002} \\
\hline S. Magnesium & $1.81 \pm 0.44$ & & & & \\
\hline Diastolic BP & $86.0 \pm 14.84$ & \multirow{2}{*}{-0.3252} & \multirow{2}{*}{0.1058} & \multirow{2}{*}{$Y=0.01 \times X+2.64$} & \multirow{2}{*}{0.001} \\
\hline S. Magnesium & $3.85 \pm 1.21$ & & & & \\
\hline
\end{tabular}

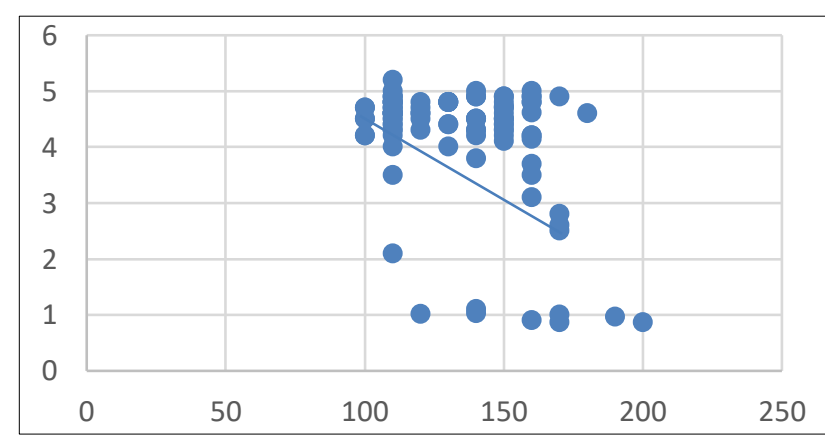

Figure 1: Correlation of systolic BP with serum ionic Ca levels.

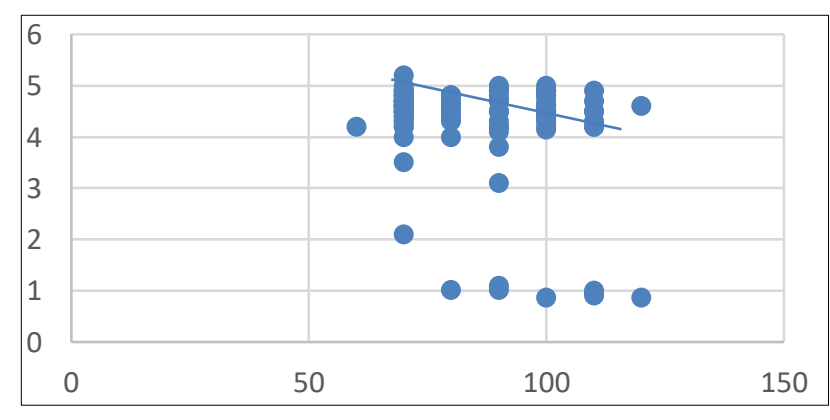

Figure 2: Correlation of diastolic BP with serum ionic Ca levels.

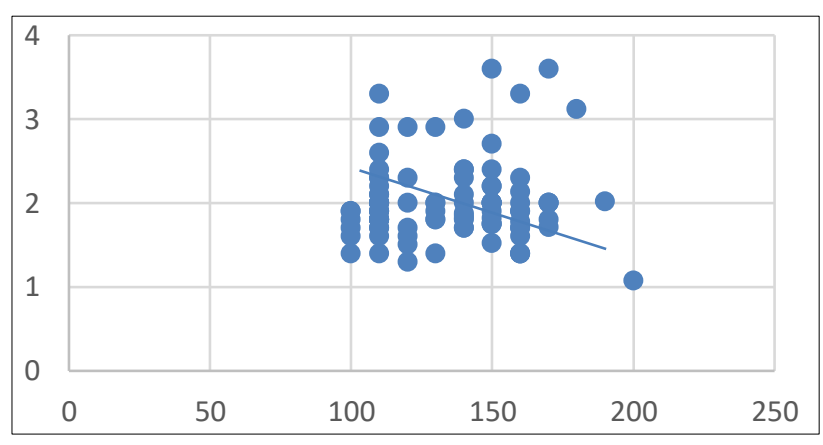

Figure 3: Correlation of systolic BP with serum magnesium levels.

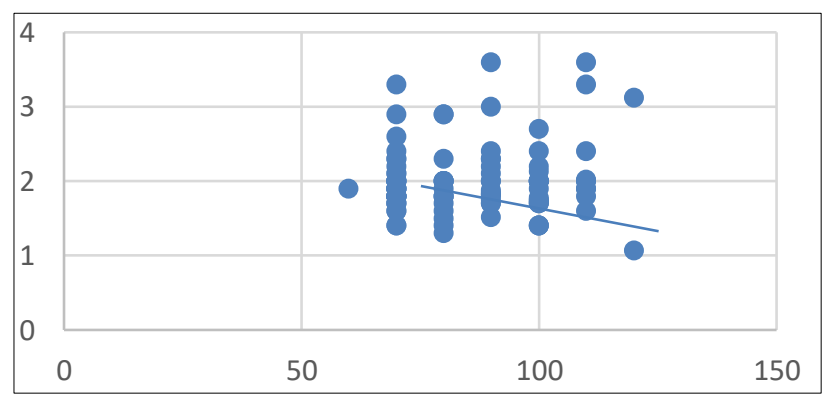

Figure 4: Correlation of diastolic BP with serum magnesium levels. 


\section{DISCUSSION}

Mineral deficiencies like calcium, magnesium, zinc, etc. have been identified to cause significant health problems for women of reproductive age, especially in developing countries due to inadequate dietary intake. The risk of deficiency becomes increased during pregnancy because of increased need of the growing fetus for various nutrients. ${ }^{1}$ Changes in levels of these elements could affect pregnancy. This study was done to compare S. ionic calcium and magnesium levels in PE and normotensive pregnancy.

Mean SBP in pre-eclamptic women was $154.6 \pm 13.43 \mathrm{~mm}$ of $\mathrm{Hg}$ and in normotensive pregnant women was $112.8 \pm 8.34 \mathrm{~mm}$ of $\mathrm{Hg}$. Difference in SBP between the two groups was statistically significant $(\mathrm{p}=0.0000)$. Mean DBP in pre-eclamptic women was $99.0 \pm 8.63 \mathrm{~mm}$ of $\mathrm{Hg}$ and in normotensive pregnant women was $73.0 \pm 5.05 \mathrm{~mm}$ of $\mathrm{Hg}$. Difference in DBP between the two groups was statistically significant $(p=0.0000)$. Our results were consistent with the observation made by Mittal et al, Kanagal, Ephraim et al, Agu and Okeudo, Chaudhari et al and Sridevi et al. ${ }^{2,17-21}$ All of them in their studies observed that SBP and DBP were significantly higher in preeclampsia as compare to control group.

Mean age of the women in study group was $27.12 \pm 3.94$ years and in control group was $24.9 \pm 2.98$ years. The difference in the age of the women in both the groups is statistically significant $(\mathrm{p}=0.03)$. Our results were in contrast with results of Agu and Okeudo, they observed that there was no significant difference in the age of women with normal pregnancy and PE. ${ }^{19}$ In our study women with PE were older than normotensive women which tally with observations of other authors, who have shown that PE is more likely to occur in women of advanced maternal age compared to younger women. ${ }^{18}$ The reason for advanced maternal age being a risk factor for PE could be related to the aging uterine vessels and subsequent defective placentation whereas other studies show no relation to age and preeclampsia. ${ }^{13,23-25}$ Illiteracy was more common in our study (approximately 50\%) as compared to various studies in the past. ${ }^{26,27}$ Study done by Opitasari et al in low-income countries, has reported that low education status poses a risk factor for PE. ${ }^{28}$ In study group, majority of the women (64\%) were overweight or obese (BMI $\geq 25 \mathrm{~kg} / \mathrm{m}^{2}$ ) and only $36 \%$ women had a normal BMI while in control group, majority of the women $(72 \%)$ had normal BMI $\left(18.5-24.9 \mathrm{~kg} / \mathrm{m}^{2}\right)$ and remaining $28 \%$ were overweight or obese (BMI $\geq 25 \mathrm{~kg} / \mathrm{m}^{2}$ ). There was statistically significant difference in both the groups $(\mathrm{p}=0.001)$. Women with greater BMI) in pregnancy are more likely to become hypertensive than those with a lower BMI. ${ }^{29}$

The serum ionic calcium concentration was significantly lower in the pre-eclamptic cases compared to the normotensive controls $(3.34 \pm 1.35$ versus $4.37 \pm 0.74$, $\mathrm{p}=0.0000)$ similarly serum magnesium concentration was significantly lower in the pre-eclamptic cases compared to the normotensive controls $(1.68 \pm 0.41$ versus $1.94 \pm 0.42$, $\mathrm{p}=0.002$ ). These findings confirmed the hypothesis that hypocalcaemia and hypomagnesaemia may be etiological factors in development of PE. Serum calcium and magnesium are very important for metabolism at the cellular level and are vital for muscle contraction, cell death and neuronal activity, making it very essential in pregnancy. The observation of low $\mathrm{Ca}^{2+}$ and $\mathrm{Mg}^{2+}$ levels is in agreement with other studies done in the past on hypertensive disorders in pregnancy.,17,18,20,21,25,30 All these authors observed in their respective studies that the serum calcium and magnesium levels were lower in women with PE than normotensive pregnant women ${ }^{30}$ while in contrast with the study done by Vafaei et al who found that serum $\mathrm{Ca}, \mathrm{Mg}$, and $\mathrm{Zn}$ levels in PE pregnant women had no significant differences with normotensive subjects and PE. ${ }^{14}$ In contrary, some researchers found that serum calcium in preeclamptic group did not differ significantly from normal pregnant group. ${ }^{31,32}$ This difference with our result may be attributed to the different socio-demographic characteristics of the population and also to the different dietary habits of the population. The observed low levels of magnesium in women with PIH and PE could be due to decreased dietary intake, increased clearance by the kidneys, haemodilution due to expansion of the extracellular space and increased consumption of minerals by the growing foetus. This together with lowered calcium levels play a role in the development of hypertensive disorders in pregnancy. Other researchers have proposed that a reduction in the level of extracellular $\mathrm{Mg}^{2+}$ causes partial membrane depolarization and decreased repolarisation along with opening of $\mathrm{Ca}^{2+}$ membrane channels, leading to an intracellular $\mathrm{Ca}^{2+}$ shift. Furthermore, the existing increase in the foetal $\mathrm{Ca}^{2+}$ demand may also block bone resorption of $\mathrm{Ca}^{2+}$ with a concurrent intracellular pull. ${ }^{30}$ This phenomenon produces vasoconstriction together with an increase in the blood pressure, as seen in PIH and PE.

In our study we found that mean S. Ca levels in severe PE group was significantly lower than normotensive pregnant women $(p=0.0000)$ as well as mild PE group $(p=0.001)$. Our results were comparable with that observed by Gupta, where severity of preeclampsia is inversely proportional to the levels of serum calcium while Vafaei et al in their study observed that serum Ca levels in PE pregnant women had no significant differences with normotensive subjects and also severity of this disorder could not influenced the serum levels of calcium. ${ }^{14,33}$ The effect of $\mathrm{Mg}^{2+}$ and $\mathrm{Ca}^{2+}$ in the pathogenesis of hypertensive disorders in pregnancy is supported by the observation of significant decrease in $\mathrm{S}$ ionic calcium and magnesium with severity of PE. Bharti et al found a significantly lower serum calcium levels among the cases and there was a strong association between hypocalcemia $(<9 \mathrm{mg} / \mathrm{dl})$ and preeclampsia. ${ }^{34}$ Mean S. magnesium in severe pre-eclampsia was significantly lower than normotensive pregnant women $(\mathrm{p}=0.0008)$ as well as mild PE group $(\mathrm{p}=0.03)$. Our results were comparable with that observed by Gupta, where 
severity of preeclampsia is inversely proportional to the levels of serum magnesium while Vafaei et al in their study observed that the serum Mg levels in PE pregnant women had no significant differences with normotensive subjects and also severity of this disorder could not influenced the serum levels of magnesium. ${ }^{14,33}$

Serum ionic calcium had a moderate negative correlation $(\mathrm{R}=-0.538)$ with SBP and DBP $(\mathrm{R}=-0.5137)$. The relation of S. ionic calcium with SBP and DBP was statistically significant $(\mathrm{p}<0.0001)$. Our results were in agreement with the results of Agu and Okeudo who observed there was an inverse relationship between serum calcium and systolic blood pressure $(\mathrm{R}=-0.684, \mathrm{p}<0.001$. $)$ as well as a negative correlation between serum calcium and diastolic blood pressure $(\mathrm{R}=-0.633, \mathrm{p}<0.001) .{ }^{19}$ Serum magnesium had a weak negative correlation $(\mathrm{R}=-0.3005)$ with SBP and DBP $(\mathrm{R}=-0.3252)$. Our results were in accordance with the results of Kharb et al who observed that the correlation between serum $\mathrm{Mg}$ at term with pre-eclamptic women was negative and statistically significant $(\mathrm{R}=-0.219$, $\mathrm{p}=0.027) .{ }^{35}$

\section{CONCLUSION}

The findings in this study revealed a significant low level of serum ionic calcium and magnesium in PE and suggest that $\mathrm{S}$. ionic calcium and magnesium may be used as markers for PE. Therefore, based on this study, serial measurements of serum ionic calcium and magnesium among women who are at risk of PE may be used to predict the onset and severity of PE. However, therapeutic intervention to supplement calcium and magnesium in pregnant women for prevention of $\mathrm{PE}$ requires further study.

\section{Funding: No funding sources}

Conflict of interest: None declared

Ethical approval: The study was approved by the Institutional Ethics Committee

\section{REFERENCES}

1. Cunningham FG, Leveno KJ, Bloom SL, Dashe JS, Hoffman BL, Casey BM, Sponge CY. Hypertensive disorder in pregnancy. Textbook of Williams Obstetrics. 25nd ed. New York: McGraw-Hill. 2014;1566-677.

2. Mittal S, Shaikh MKS, Thakur R, Jain D. Comparison of serum calcium and magnesium levels between preeclamptic and normotensive healthy pregnant women. Int J Reprod Contracept Obstet Gynecol. 2014;3:959-62.

3. Adewolu OF. Serum sodium, potassium, calcium and magnesium in women with pregnancy-induced hypertension and preeclampsia in Oredo local government, Benin metropolis: A pilot study. Afr J Med Health Sci. 2013;12:1-5.

4. Baruah K, Choudhury B, Borgohain MK, Choudhury NH. A comparative study of the serum calcium level in normal pregnant and pre-eclamptic women attending Gauhati Medical College and Hospital. Int J Biomed Adv Res. 2015;6:776-9.

5. Cunningham FG, Leveno KJ, Bloom SL, Hauth JC, Gilstrap LC, Wenstrom KD, Hypertensive disorder in pregnancy. Textbook of Williams Obstetrics. 22nd ed. New York: McGraw-Hill. 2005;761-808.

6. Roberts JM, Cooper DW. Pathogenesis and genetics of pre-eclampsia. Lancet. 2001;357:53-6.

7. Chaurasia PP, Jadav PA, Jasani JH. Changes in serum calcium and serum magnesium level in preeclampsia vs normal pregnancy. Int $\mathbf{J}$ Biomed Adv Res. 2012;3:511-3.

8. Sarwar MS, Ahmed S, Ullah MS, Kabir H, Rahman GKMM, Hasnat A, et al. Comparative Study of Serum Zinc, Copper, Manganese and Iron in Pre-eclamptic Pregnant Women. Biol Trace Elem Res. 2013;154:1420.

9. Akinloye O, Oyewale OJ, Oguntibeju OO. Evaluation of trace elements in pregnant women with preeclampsia. Afr J Biotechnol. 2010;9:5196-202.

10. Ugwuja EI, Famurewa AC, Ikaraoha CI. Comparison of serum calcium and magnesium between preeclamptic and normotensive pregnant Nigerian women in Abakaliki, Nigeria. Ann Med Health Sci Res. 2016;6:33-7.

11. Chappell LC, Seed PT, Briley A, Kelly FJ, Hunt BJ, Charnock-Jones DS, et al. A longitudinal study of biochemical variables in women at risk of preeclampsia. Am J Obstet Gynecol. 2002;187:127-36.

12. Abdellah A, Abdrabo AKA. Assessment of serum calcium, magnesium, copper and zinc levels in Sudanese pregnant women with pre-eclampsia. Global Adv Res J. 2014;3(2):33-6.

13. Golmohammad lou S, Amirabi A, Yazdian M, Pashapour N. Evaluation of Serum Calcium, Magnesium, Copper and Zinc Levels in Women with Pre-eclampsia. Iran J Med Sci. 2008;33:231-4.

14. Vafaei H, Dalili M, Hashemi SA. Serum concentration of calcium, magnesium and zinc in normotensive versus pre-eclampsia pregnant women: A descriptive study in women of Kerman province of Iran. Iran J Reprod Med. 2015;13:23-6.

15. Tong GM, Rude RK. Magnesium deficiency in critical illness. J Intensive Care Med. 2005;20:3-17. 12. 12 Touy ZRM. Role of magnesium deficiency in pathogenesis of hypertension. Mol Aspects Med. 2003;24:107-36.

16. Villar J, Merialdi M. Nutritional interventions during pregnancy for the prevention or treatment of maternal morbidity and preterm delivery: An overview of Randomised controlled Trials. J Nutr. 2003;133:160625.

17. Kanagal DV, Rajesh A, Rao K. Levels of Serum Calcium and Magnesium in Pre-eclamptic and Normal Pregnancy: A Study from Coastal India. J Clin Diagn Res. 2014;8(7):1-4.

18. Ephrain RKD, Derick NMO, Seth WD, Henrietta E, Samuel A, Enoch OA. Serum calcium and magnesium levels in women presenting with preeclampsia and 
pregnancy-induced hypertension: a casecontrol study in the Cape Coast metropolis, Ghana. BMC Pregnancy and Childbirth. 2014;14:390.

19. Agu CT, Okeudo C. A Comparative Study of Serum Calcium Levels between Pre-eclamptic and Normotensive Singleton Pregnancies in Federal Medical Centre, Owerri. J Adv Med Medical Res. 2018;27(11):1-8.

20. Chaudhari RK, Niraula A, Bataju M, Baranwal JK, Khan SA, Bhatt RD, Chettri S, Lamsal M. Serum Calcium and Magnesium levels in Pre-eclampsia. Nat J Lab Med. 2018;7(4):1-6.

21. Sridevi C, Sowjanya UVPU. Study of serum calcium, magnesium and uric acid in preeclampsia and its comparison with normal pregnancy. Int J Adv Res. 2019;7:1521-4.

22. Owiredu WKBA, Ahenkorah L, Turpin CA, Amidu $\mathrm{N}$, Laing EF. Putative risk factors of pregnancyinduced hypertension among Ghanaian pregnant women. JMBS. 2012;1(3):62-76.

23. Kasiulevicius V, Sapoka V, Filpavicrute R. Sample size calculation in epidemiological studies. Gerontologija. 2006;7(4):225-31.

24. Akhtar S, Begum S, Ferdousi S. Calcium and Zinc Deficiency in Pre-eclamptic Women. J Bangldesh Soc Physiol. 2011;6(2):94-9.

25. Sukonpan K, Phupong V. Serum calcium and serum magnesium in normal and pre-eclamptic pregnancy. Arch Gynecol Obstet. 2005;273:12-6.

26. Gupta A, Kant S, Pandav CS, Gupta SK, Rai SK, Misra P. Dietary calcium intake, serum calcium level, and their association with preeclampsia in rural North India. Indian J Comm Med. 2016;41:223-7.

27. Sende PP, Isah AY, Nwegbu MM, Ekele BA, Agida TE, Adebayo FO. Plasma Calcium Levels in
Preeclampsia Versus Normotensive Pregnant Women in a Tertiary Hospital: A Comparative Study. J Fetal Med. 2019;6:25-30.

28. Opitasari C, Andayasari L. Parity, Education level and risk for (Pre-) eclampsia in selected hospitals in Jakarta. Health science Indones. 2013;1:35-9.

29. Pipkin FB. Risk factors for preeclampsia. N Engl J Med. 2001;344:925-6.

30. Indumati V, Kodiwadmath MV, Sharma M.K. The role of serum electrolyte in pregnancy induced hypertension. J Clin Diagn Res. 2011;5(1):66-9.

31. Vahidrodsari F. Serum calcium and magnesium in preeclamptic and normal pregnancies; A comparative study. J Reprod Infert. 2008;9(3):36-8.

32. I-Bera-S, Siuli- RA. Study of serum electrolytes in pregnancy induced hypertension. Indian Med Assoc. 2011;109(8):546-8.

33. Gupta P. A study of maternal serum calcium and serum magnesium levels in pre-eclamptic and normotensive pregnancies. Int J Reprod Contracept Obstet Gynecol. 2020;9(8):3129-33.

34. Bharti A, Kumar S, Bhushan M, Singh SK. Serum calcium and magnesium in preeclampsia and normal pregnancy. Int J Med Health Res. 2018;4(4):187-9.

35. Kharb S, Goel K, Bhardwaj J, Nanda S. Role of magnesium in preeclampsia. Biomed Biotechnol Res J. 2018;2:178-80.

Cite this article as: Sethi S, Chaudhary A, Sonkhya P, Mital P, Arora A, Kasana VK, Agarwal I. A comparative study of serum calcium and magnesium levels in women with pre-eclampsia and normotensive women. Int J Reprod Contracept Obstet Gynecol 2021;10:2420-26. 